\title{
Linear correlations between feed intake and ingestive behavior of feedlot lambs
}

\author{
IState University of Piauí, Teresina, Brazil \\ ${ }^{2}$ State University of Southwest of Bahia, Vitoria da Conquista, Brazil \\ ${ }^{3}$ Federal University of Piaui, Teresina, Brazil \\ *Corresponding author, email: hsantanajunior@hotmail.com
}

Cibelle Borges Figueiredo', Hermogenes Almeida Santana Junior'*, Aracele Prates Oliveira², Maurílio Souza dos Santos ${ }^{3}$, Fabrício Bacelar Lima Mendes², Elizângela Oliveira Cardoso-Santana²

\begin{abstract}
The objective of this study was to evaluate linear correlations between feed intake and ingestive behavior of feedlot lambs. Were used ten castrated male Santa Inês sheep with a body weight of $20 \pm 4.38 \mathrm{~kg}$, at four months of age. The experiment lasted 50 days, with five 10-d periods, in which an evaluation of feed intake and ingestive behavior was undertaken per period, totaling 50 replicates. The diet was composed of concentrate ingredients only. The analyses were performed by Pearson's linear correlations and the t test, and means were considered significant when $P \leq 0.05$. Intake showed positive correlations $(P \leq 0.05)$ with the times spent feeding and ruminating and total chewing time, and a negative correlation $(P \leq 0.05)$ with other activities. Positive correlations were found between the number of feeding periods, number of other activities and the time per rumination period with intake ( $P \leq 0.05)$. A negative correlation was found between the feed efficiency of dry matter and the intake, as well as the other nutrients $(P \leq 0.05)$. The behavioral characteristics related to feed intake appear to be correlated, which allows for inferences through the study of these variables. The activities related to nutrient intake, with respect to time and efficiency, can be expressed directly through the animal behavior.
\end{abstract}

Keywords: concentrate, ethology, ruminants, sheep

\section{Introduction}

The study of the ingestive behavior has been used as a tool to evaluate diets that allows for the adjustment of the animal-feeding management in order to achieve better performance (Confortin et al., 2010; Pereira et al., 2011 ; Pinheiro et al., 2011; Santana Júnior et al., 2013b), guiding and reinforcing various discussions about intake. Thus, these associations are cited as hypotheses rather than the objective of research, and so the measurements of these correlations may break some paradigms, because probably not all behavioral variables are correlated with productive results (Santana Júnior et al., 2013a).

Knowledge of the ingestive-behavior variables that inter-correlate with the intake is necessary so as to determine which variables should compose a mathematical model that determines intake through the feeding behavior (Carvalho et al., 2007).

Allden \& Whittaker (1970) developed the basis of this proposal, wherein they claim that the daily intake of a grazing animal is the product of grazing time and bite rate. This concept was improved by Rook (2000), who suggested intake as being the product of bite mass (BM) and bite rate (BR) and the duration (DM) and number of meals (NM) over the day, as follows:

Intake $=(B M \times B R) \times(D M \times N M)$ 
Based on the information contained in the Brazilian scientific publications on behavioral variables, there is a possibility of estimating the feed intake of animals using them; however, many researchers trivialize the use of any predictor model without properly investigating the cause-effect relationships of the feeding process, regarding them as "emerging variables" and additional information (Carvalho et al., 2007).

The objective of this study was to evaluate linear correlations between the feed intake and ingestive behavior of feedlot lambs.

\section{Materials and Methods}

The experiment was conducted in the Laboratory of Experiments on Animal Nutrition (Laboratório de Ensaios Nutricionais em Animais; LENA) at the Center for Teaching and Research on Animal Nutrition (Centro de Ensino e Pesquisa em Nutrição Animal; CEPENA), located on Campus Deputado. Jesualdo Cavalcanti de Barros of Universidade Estadual do Piauí. Were used ten castrated male Santa Inês sheep with a body weight of $20 \pm 4.38 \mathrm{~kg}$, at four months of age. The animals were identified by numbered plastic earrings, and subsequently allocated to individual $1.0 \times 1.0 \mathrm{~m}$ stalls containing individual bucket-type feed and water troughs. This study was approved by the Ethics Committee on Animal Use at the State University of Piaui under the Protocol 10922/15.

The experiment lasted 50 days, with five 10-d periods, in which one evaluation of feed intake and ingestive behavior was undertaken per period, totaling 50 replicates. The diet consisted of concentrate ingredients: ground corn $(55.76 \%)$, cottonseed meal cake $(37.17 \%)$ and a vitamin-mineral-buffer premix (7.07\%).

Feed was supplied daily at $7 \mathrm{~h} 30$ at $15 \mathrm{~h} 45$. The animals received feed-supply levels of 100 , $95,90,85$ and $80 \%$, aiming to promote variations in feed intake and ingestive behavior. Feed intake was quantified for four days, from the 7th to 10th day of each period (Table 1), by measuring the amount of feed supplied and subtracting the orts, avoiding losses or discounting the losses, which were measured on the respective days subsequent to the supply, always in the morning before the supply.

Table 1. Daily intake of feedlot lambs

\begin{tabular}{lcc}
\hline \multicolumn{1}{c}{ Item } & Intake & CV' \\
\hline Dry matter (g/day) & 825.44 & 12.81 \\
Organic matter (g/day) & 749.72 & 12.81 \\
Crude protein (g/day) & 125.9 & 12.81 \\
Neutral detergent fiber corrected for ash and protein (g/day) & 160.48 & 12.81 \\
Non-fibrous carbohydrate (g/day) & 356.8 & 12.81 \\
Ether extract (g/day) & 106.52 & 12.81 \\
\hline 'Coefficient of variation & &
\end{tabular}

Fecal production was evaluated from the 7th to the 9th day of each period by total fecal collection. The collections were performed using a polyethylene screen placed below the slatted floor, free of any contaminations. The samples of feces were weighed in the morning, and approximately $10 \%$ of the total was taken. A composite sample was formed per animal per experimental period, referring to the three days of collection performed in each period. The apparent digestibility coefficients of the dry matter and nutrients were estimated as the ratio between fecal output and the daily intake.

The chemical composition of the feed supplied, orts and feces was evaluated by drying these materials in a forced-ventilation oven at $55^{\circ} \mathrm{C}$ for 72 hours, and then analyzing the levels of dry matter (DM), crude protein (CP), ether extract (EE), neutral detergent fiber (NDF), acid detergent fiber (ADF) and ash, which were obtained according to methodologies described by Detmann et al. (2012). The NDF content was corrected for ash and protein (NDFap), following recommendations of Mertens (2002). The nonfibrous carbohydrates (NFC) were obtained by the following equation citated by Sniffen et al. (1992): NFC $=100-(\% C P+\% E E+\% N D F a p$ $+\%$ Ash). The analysis revealed that the diet contained DM, CP, NDFap, EE, ash, NFC and TDN concentrations of $914 \mathrm{~g} / \mathrm{kg}$ fresh matter, $152 \mathrm{~g} / \mathrm{kg}$ 
DM, 194 g/kg DM, 100 g/kg DM, 92 g/kg DM, 432 $\mathrm{g} / \mathrm{kg} \mathrm{DM}$ and $650 \mathrm{~g} / \mathrm{kg} \mathrm{DM}$, respectively.

The ingestive behavior was evaluated on the 10th day of each experimental period by making observations at every five minutes, using digital stopwatches, in accordance with the methodology of Carvalho et al. (2011), for 24 hours, aiming to identify the time spent on chewing, rumination, and other activities. The animals were visually assessed by two trained observers, which switched places at every four hours.

The studied behavioral variables were: feeding time (FT), rumination time (RT) and time on other activities (TO). The behavioral variables were considered mutually exclusive.

The feeding time was the time taken by the animal to consume the diet. The rumination time corresponded to the processes of regurgitation, re-chewing, re-salivation and re-swallowing. And the time on other activities was considered to be the actions that have no nutritional relevance (rest, water intake, interactions, etc.).

The total chewing time (TCT) was determined by the equation: $\mathrm{TCT}=\mathrm{FT}+\mathrm{RT}$, where; FT = feeding time ( $\mathrm{min})$, RT = rumination time (min). The discretization of time series was performed directly on the data collection spreadsheets, counting the discrete periods of feeding, rumination, and other activities. The average duration of each one of the discrete periods was obtaining by dividing the time spent daily on each activity by the number of the discrete periods of the referred activity.

Three observations were made per shift, aiming to determine the number of chews per ruminated bolus (NCB) and the time spent to ruminate each bolus (TRB). The variables number

Table 2. Linear correlations between ingestive behavior and feed intake in feedlot lambs

\begin{tabular}{|c|c|c|}
\hline \multirow{2}{*}{ Item } & \multicolumn{2}{|c|}{ Intakel } \\
\hline & r & $\mathrm{P}$ \\
\hline Feeding time (min) & 0.67 & 0.0000 \\
\hline Rumination time (min) & 0.49 & 0.0001 \\
\hline Time on other activities (min) & -0.67 & 0.0000 \\
\hline Total chewing time (min) & 0.67 & 0.0000 \\
\hline
\end{tabular}

ether extract and non-fibrous carbohydrates

Although the time on other activities is comprised of actions without nutritional relevance (rest, interactions, etc.), the behavioral activities of boli ruminated per day (NBD), chewing speed (CS), time on rumination chewing (TRC) and rumination chews per day (RCD) were calculated by the equations: NBD = RT/TRB, where; NBD (n/ day), RT (s/day) and TRB (s); CS = RCD/TRB, where; CS (s), RCD (n/day) and TRB (s); TRC = TRB/NCB, where: $\operatorname{TRC}(\mathrm{s}), \operatorname{TRB}(\mathrm{s})$; NCB (n/bolus); and RCD $=N B D \times N C B$, where; RCD (n/day), NBD (n/day) and NCB (n/bolus).

The feed efficiency of DM, NDF, TDN, NFC and $\mathrm{CP}$, in grams per minute, and the rumination efficiency of DM and NDFap were calculated by dividing the intake of each component by the total feeding time (feed efficiency) or by the rumination time (rumination efficiency).

Correlations were made by analysis of Pearson's linear correlations and the t test, and processed on the SAEG (Sistema de Análises Estatísticas e Genéticas, version 9.0) software. The correlations were considered significant when $\mathrm{P}<0.05$.

\section{Results and Discussion}

The times spent on feeding and rumination and the total chewing time had positive correlations $(\mathrm{P} \leq 0.05)$ with intake (Table 2). Because the diets had the same proximate composition, but at differents levels of supply, lambs had similar intake for all nutrients. The present study corroborates Gontijo Neto et al. (2006), who reported that the feeding time is correlated with feed intake. Agreeing with the effect observed in this study, Figueiredo et al. (2013) cite that there is a correlation between rumination and NDF intake; however, in the current experiment there was a weak correlation between the two variables because the diet contained only $21.23 \%$ NDFap. are mutually exclusive; therefore, to obtain a greater feed intake, the feeding time should be increased, which will lead to a decrease in the 
time spent on other activities (Santana Júnior et al., 2013c). This fact is explained by the negative correlation between the time on other activities and intake $(\mathrm{P}<0.05)$.

The total chewing time (TCT) is directly related to the feeding time (FT), because this variable is part of the formula to determine the TCT. Santana Júnior et al. (2012) state that longer chewing is a result of the elevation in the fiber content of the diet. Because only concentrate ingredients were used in the present study, TCT and FT are associated due to the lower rumination time, which resulted from the low dietary concentration of fibrous carbohydrates. Positive correlations were found between number of feeding periods, periods on other activities and the time per rumination period with feed intake $(P<0.05)$ (Table 3$)$. The increase in the number of feeding cycles in confinement conditions where the animals received their food without a roughage results in greater nutrient intake. Mendes Neto et al. (2007) report that the change in time or frequency of supply of the diet to the animal can modify the percentage distribution of the feeding times of feedlot animals.

Table 3. Linear correlations between discrete periods of the ingestive behavior and feed intake in feedlot lambs

\begin{tabular}{lcc}
\hline \multicolumn{1}{c}{ Item } & \multicolumn{1}{c}{ Intake $^{1}$} & P \\
\cline { 2 - 3 } Number of feeding periods & 0.79 & 0.0000 \\
Number of rumination periods & -- & -- \\
Number of periods on other activities & 0.69 & 0.0000 \\
Time per feeding period (min) & -0.43 & 0.0010 \\
Time per rumination period (min) & 0.37 & 0.0041 \\
Time per period on other activities (min) & -0.60 & 0.0000 \\
\hline 'The intake can be considered both total, in terms of dry matter, and of nutrients, organic matter, crude protein, neutral detergent fiber corrected for ash and protein,
\end{tabular}

ether extract and non-fibrous carbohydrates

The number of rumination periods did not correlate with any intake variable $(P>0.05)$, due to the ability that sheep have to select ingredients, wherein sometimes there is a greater intake of corn or cottonseed cake, which causes changes in the rumination frequencies. In general, foods rich in starch and sucrose are rapid fermentable (Rech et al., 2013); this causes an increase in the propionate concentrations in the rumen, which may result in a chemical limitation, which explains these oscillations in the rumination process.

Regarding the number of periods on other activities, the increased intake is a consequence of the higher frequency of periods on other activities, because the animal displays a greater intake and also rests more often, which does not mean a longer rest time. The time per feeding period showed a negative correlation
$(P<0.05)$, having an opposite behavior to the number of feeding periods, because an increase in the number promotes reduction of the time.

Because the behavioral activities are mutually exclusive, the time per period on other activities showed a negative correlation with the intake variable ( $P>0.05)$; this is related to the time spent on other activities during which the animal is not consuming the diet.

The number of boli ruminated per day and rumination chews per bolus showed positive and low correlations with intake $(P \leq 0.05)$, and no correlation was found for the number of rumination chews per bolus or speed and time of chewing with feed intake ( $P>0.05)$ (Table 4). The rumination activities depend on the dry matter intake and the effective fiber content in the diets. Regardless of the food, the chewing time during

Table 4. Linear correlations between rumination aspects of ingestive behavior and feed intake in feedlot lambs

\begin{tabular}{lcc}
\hline \multicolumn{1}{c}{ Item } & \multicolumn{2}{c}{ Intake l $^{1}$} \\
\cline { 2 - 3 } Number of chews per ruminated bolus & $\mathrm{r}$ & --- \\
Number of boli ruminated per day & -- & 0.45 \\
Chewing speed (n/s) & --- & 0.005 \\
Time on rumination chewing (s) & --- & -- \\
Number of rumination chews per day & 0.42 & 0.0013 \\
\hline
\end{tabular}

The intake can be considered both total in terms of dry matter, and of nutrients, organic matter, crude protein, neutral detergent fiber corrected for ash and protein, ether extract and non-fibrous carbohydrates 
rumination may facilitate the hydration of the particles, in addition to breaking physical barriers, which facilitates microbial colonization (Kozloski, 2009).

A negative correlation was found between the feed efficiency of dry matter and intake $(P<0.05)$ (Table 5). This effect can be explained by the greater nutrient density of the diets, wherein the increase in total dry matter intake reduced as the concentrate levels were increased. Thus, the optimal level of concentrate in the diet is variable, whose decisive factors are sex, breed, age and quality of the roughage and concentrate (Medeiros et al., 2007).

Table 5. Linear correlations between efficiencies of ingestive behavior and feed intake in feedlot lambs

\begin{tabular}{|c|c|c|}
\hline \multirow{2}{*}{ Item } & \multicolumn{2}{|c|}{ Intakel } \\
\hline & $r$ & $P$ \\
\hline Feed efficiency of dry matter & -0.27 & 0.0292 \\
\hline Rumination efficiency of dry matter & --- & --- \\
\hline Rumination efficiency of NDFap ${ }^{2}$ & --- & --- \\
\hline
\end{tabular}

The absence of correlations between rumination efficiency of DM and NDFap with feed intake $(P>0.05)$ is linked to a bilateral effect, in which the highest and lowest concentrations of effective fiber present in the cottonseed cake and corn, respectively, caused an inconsistent rumination. Mertens (1996) asserts that if diets have a low fiber content, the rumen fermentation is reduced. According to Lima et al. (2013) and Figueiredo et al. (2013), the rumination efficiency is affected by the intakes of DM and NDFap, positively or negatively. Fontenelle et al. (2011) mention that a prolonged rumination activity does not always compensate for a reduction in rumination efficiency.

\section{Conclusions}

The behavioral characteristics related to feed intake appear to be correlated, which allows for inferences through the study of these variables. The activities related to nutrient intake, with respect to time and efficiency, can be expressed directly through the animal behavior.

\section{References}

Allden, W.G., Whittaker, A.M. 1970. The determinants of herbage intake by grazing sheep: the interrelationship of factors influencing herbage intake and availability. Australian Journal Agricultural Research 21:755-766.

Carvalho, G.G.P., Garcia, R., Pires, A.J.V., Silva, R.R., Detmann, E., Ribeiro, E.L.O. 2011 . Evaluation of intervals between observations on estimation of eating behavior of cattle. Revista Brasileira de Zootecnia 40:2502-2509.

Carvalho, P.C.F., Kozloski, G.V., Ribeiro Filho,
H.M.N., Reffatti, M.V., Genro, T.C.M., Euclides, V.P.B. 2007. Avanços metodológicos na determinação do consumo de ruminantes em pastejo. Revista Brasileira de Zootecnia 36:151170.

Confortin, A.C.C., Bremm, C., Rocha, M.G., Silva, J.H.S., Gomes, D.A., Camargo, E.D.G., Rosa, A.T.N. 2010. Padrões de comportamento ingestivo de cordeiras recebendo ou não suplemento em pastagem de milheto. Ciência Rural 40:25552561.

Detmann, E., Souza, M.A., Valadares Filho, S.C., Queiroz, A.C., Berchielli, T.T., Saliba, E.O.S., Cabral, L.S., Pina, D.S., Ladeira, M.M., Azevedo, J.A.G. 2012. Métodos para análises de alimentos. Instituto Nacional de Ciência e Tecnologia de Ciência Animal. (ed.) Viçosa: Visconde do Rio Branco, 214p.

Figueiredo, M.R.P., Saliba, E.O.S., Borges, I., Rebouças, G.M.N., Aguiar, F., Silva, E., Sá, H.C.M. 2013. Comportamento ingestivo de ovinos alimentados com diferentes fontes de fibra. Arquivo Brasileiro de Medicina Veterinária e Zootecnia 65:485-489.

Fontenele, R.M., Pereira, E.S., Carneiro, M.S.S., Pimentel, P.G., Cândido, M.J.D., Regadas Filho, J.G.L. 2011. Consumo de nutrientes e comportamento ingestivo de cordeiros da raça Santa Inês alimentados com rações com diferentes níveis de energia metabolizável. Revista Brasileira de Zootecnia 40:1280-1286.

Gontijo Neto, M.M., Euclides, V.P.B., Nascimento Junior, D., Miranda, L.F., Fonseca, D.M., Oliveira, M.P. 2006. Consumo e tempo diário de pastejo por novilhos Nelore em pastagem de capimtanzânia sob diferentes ofertas de forragem. Revista Brasileira de Zootecnia 35:60-66.

Kozloski, G.V. 2009. Bioquímica dos ruminantes. 2. ed. Santa Maria: Ed. UFSM, $216 \mathrm{p}$. 
Lima, F.H.S., Gonzaga Neto, S., Leite, S.V.F., Melo, A.A.S., Sousa, J.E.L., Moura, J.F.P., Lima, J.S.B., Costa, T.P. 2013. Comportamento ingestivo de vacas primíparas das raças Guzerá e Sindi recebendo dietas com diferentes níveis de ureia. Ciência Rural 43:709-715.

Medeiros, G.R., Carvalho, F.F.R., Ferreira, M.A., Batista, A.M.V., Alves, K.S., Maior Júnior, R.J.S., Almeida, S.C. 2007. Efeito dos níveis de concentrado sobre o desempenho de ovinos Morada Nova em confinamento. Revista Brasileira de Zootecnia36:1162-1171.

Mendes Neto, J., Campos, J.M.S., Valadares Filho, S.C., Lana, R.P., Queiroz, A.C., Euclydes, R.F. 2007. Comportamento ingestivo de novilhas leiteiras alimentadas com polpa citríca em substituição ao feno de capim-tifton 85. Revista Brasileira de Zootecnia 36:618-625.

Mertens, D.R. 1996. Using fiber and carbohydrate analyses to formulate dairy rations. In: Informational Conference with Dairy and Forages Industries. US Dairy Forage Research Center, p. 81-92.

Mertens, D.R. 2002. Gravimetric determination of amylase-treated neutral detergent fiber in feeds with refluxing in beakers or crucibles: collaborative study. Journal of AOAC International 85:12171240.

Pereira, E.S., Pimentel, P.G., Carneiro, M.S.S., Mizubuti, I.Y., Ribeiro, E.L.A., Rocha Júnior, J.N., Costa, M.R.G.F. 2011 . Comportamento ingestivo de vacas em lactação alimentadas com rações à base de torta de girassol. Semina: Ciências Agrárias 32:1201-1210.

Pinheiro, A.A., Veloso, C.M., Rocha Neto, A.L., Silva, R.R., Silva, F.F., Mendes, F.B.L., Santana Júnior, H.A., Azevedo, S.T., Carvalho, G.G.P. 2011. Comportamento ingestivo de novilhas leiteiras alimentadas com níveis de farelo de cacau (Theobroma cacao) na dieta. Revista Brasileira de Saúde e Produção Animal 13:224-236.

Rech, C.L.S., Rech, J.L., Santana Júnior, H.A., Cardoso, A.S. 2013. Ruminantes. Fundamentos fisiológicos e nutricionais. Eduneb, Salvador, Bahia. 248p.

Rook, A.J. 2000. Principles of foraging and grazing behaviour. In: Hopkins, A. (Ed.). Grass, its production and utilization. Blackwell Science Ltda, Oxford, England. p.229-246.

Santana Júnior, H.A., Silva, R.R., Carvalho, G.G.P. Cardoso, E.O., Mendes, F.B.L., Pinheiro, A.A., Abreu Filho, G., Dias, D.L.S., Barroso, D.S., Silva, F.F., Trindade Júnior, G. 2013a. Comportamento ingestivo de novilhas suplementadas a pasto sob nutrição compensatória. Archivos de Zootecnia
$62: 61-71$

Santana Júnior, H.A., Silva, R.R., Carvalho, G.G.P., Silva, F.F., Barroso, D.S., Pinheiro, A.A., Abreu Filho, G., Cardoso, E.O., Dias, D.L.S., Trindade Junior, G. 2013b. Correlação entre desempenho e comportamento ingestivo de novilhas suplementadas a pasto. Semina: Ciências Agrárias 34:367-376.

Santana Júnior, H.A., Silva, R.R., Carvalho, G.G.P., Silva, F.F., Trindade Júnior, G., Pinheiro, A.A., Rodrigues, E.S.O., Abreu Filho, G., Santana, E.O.C., Mendes, F.B.L. 2013c. Correlation between intake and ingestive behavior of pasture-grazed heifers. Semina: Ciências Agrárias 34:2963-2976.

Santana Júnior, H.A., Silva, R.R., Carvalho, G.G.P., Silva, F.F., Mendes, F.B.L., Abreu Filho, G., Trindade Júnior, G., Cardoso, E.O., Barroso, D.S., Pereira, M.M. 2012. Correlação entre digestibilidade e comportamento ingestivo de novilhas suplementadas a pasto. Archivos de Zootecnia 61:549-558.

Sniffen, C.J., O'connor, J.D., Van Soest, P.J., Fox, D.G., Russell, J.B. 1992. A net carbohydrate and protein system for evaluating cattle diets: IICarbohydrate and protein availability. Journal of Dairy Science 70:3562-3577. 